\title{
The Socio-Cultural Perception of Death in Turkish Society Recorded in Lament Epics (1955- 1975)
}

Article in OMEGA--Journal of Death and Dying · January 2014

DOI: 10.2190/OM.70.2.d· Source: PubMed

CITATIONS

0

5 authors, including:

\section{Cumhur Izgi}

Akdeniz University

6 PUBLICATIONS 2 CITATIONS

SEE PROFILE
READS

39

Mustafa Coban

Akdeniz University

7 PUBLICATIONS 4 CITATIONS

SEE PROFILE

Some of the authors of this publication are also working on these related projects:

Project

In this study, variations in applcations on health at home and home care services in legislative base have been investigated View project

Project

Care for Carers View project

All content following this page was uploaded by Cumhur Izgi on 03 December 2015. 
OMEGA, Vol. 70(2) 209-223, 2014-2015

\title{
THE SOCIO-CULTURAL PERCEPTION OF DEATH IN TURKISH SOCIETY RECORDED IN LAMENT EPICS (1955-1975)
}

\section{CUMHUR IZGi}

TARANA ABDULLA

MUSTAFA ÇOBAN

Akdeniz University, Turkey

EBRU ONAY

Bilkent University, Turkey

E. ELIF VATANAOGLU LUTZ

Yeditepe University, Turkey

\begin{abstract}
This study explores the socio-cultural perception of death among Turkish people. For this reason, 210 published lament epics written by Turkish folk singers across all of Turkey concerning deaths between 1955 and 1975 were selected for analysis. These epics were published on single pages and were sold. The statistical analysis based on detailed content analysis was done at the univariate, bivariate, and multivariate levels. The results of the study provide a full picture of perception of cases of death in Turkish society. These results show Turkish society is especially sensitive to cases of death at young age and to the murdered. Further, a clear perception of the working of fate is encountered in deaths resulting from disaster and accidents; but the desire for vengeance is recorded in those laments concerning martyrs and the murdered. The statistical data show that most commonly cited reasons for death after road accidents, were a consequence of relationships with the opposite sex and from a sense of honor.
\end{abstract}

209

(C) 2014, Baywood Publishing Co., Inc. doi: http://dx.doi.org/10.2190/OM.70.2.d

http://baywood.com 
210 / iZGIET AL.

\section{GENERAL PERCEPTION OF DEATH IN TURKISH SOCIETY}

Communication and mobility among people, societies, and cultures increases everyday, a consequence of globalization. This mobility also increases the temporal distribution of grief and sorrow from death. Although the aims of globalization are power and wealth, this situation of being brought closer together brings with it the necessity of understanding and recognizing individuals from different cultures, and the emotions of fear and loneliness require that individuals share these feelings with others. It is obvious that awareness of cultural factors has an important role in this sharing. Written documents form a large part of cultural elements and evaluating the perception of death from written material is also important in distributing and sharing knowledge through written cultural elements. Lament epics are one of the sources through which we can observe the attitudes of individuals confronting death, grief and sorrow. In this research, the lament epics reflecting the values relating to death which are widely read in Turkish society have been evaluated. Understanding the perception of death in Turkish society will help us to compare the different perceptions of death in different societies and this sharing is important in order to understand the anonymous nature of death in the globalized world.

In Turkish society death and its subsequent process are the most spoken and remarked upon area as death attracts even more attention than birth. One of the facts indicating the importance of the death are the associated social rituals. The person is commemorated following his/her death on the 7th, 40th, and 52nd day. The birthdays of many leaders, politicians, and artists aren't celebrated by the society, but the anniversaries of their deaths are commemorated in memory, such as the deaths of Atatürk, Mehmet Akif, and Nazim Hikmet. If a relative of the deceased sees the deceased in his/her dream, it doesn't matter how long ago they died, in the following days the relative will try to make a cake and halvah and to give it in memory of the deceased.

First death occurs and for a moment the person is forgotten as the sense of pity for him/her is suspended for a moment while the following questions are asked: How old was he/she? How did it happen? Was he/she sick? Why did he/she die? Although people have a value or interest in society while they were alive, they acquire a greater interest and value when they die. Intrinsically, loving the living is not a very common understanding in society, while society gives an extreme value to the dead person. For this reason and only in terms of death, Turkish society can be conceptualized as a lover of death and gloom. Any negative characteristics and any evil actions made while living by the now deceased, are immediately forgotten. For example, if a hated and disputatious person dies, everything that happened in the past is forgotten in a flash. Afterwards, when the imam asks a question, such as, "How did you know him/her?," all answer with one accord, "We knew him/her as a good one," or 
"Were you pleased with the deceased?" the answer given is, "We were pleased with the deceased" (Kizilçelik, 2000, pp. 137-138).

\section{METHOD}

The aim of this study is to evaluate the treatment of cases of death in the lament epics written by Turkish folk singers that carry indications of the sociocultural perception of death among Turkish people. In the National Library of Turkey, those epics published between 1955 and 1975 were researched and in total 402 epics were found. The period from 1955-1975 was the most productive and final period in the history of Turkey for the writing of these verses and at that time there was also great interest taken in them by the people. The increasing prevalence of the written press and television, and also political tensions and hostility in society, caused the decrease in epics and, after 1975, interest in these verses almost completely disappeared.

These epics were assessed through statistical analysis based on detailed content analysis. An evaluation of the lament epics, the product of folk literature, and an assessment is reached as to the thoughts and judgments of Turkish society concerning deaths, especially deaths at a young age, the different perceptions of male and female deaths, as also in respect to revenge and fatalism. All these epics were evaluated by two independent researchers. The aim of such a method is to eliminate faults deriving from the researchers. The different evaluations of these two researchers were examined by a third. The researchers did not read more than 30 epics in a day, as these epics concerning death could cause an increase in anxiety in the researchers.

\section{FINDINGS}

Most of the studied epics have long, gloomy titles, preparing the listener/ speaker for these events. The long titles of these epics, different from the epics of the oral periods, state almost completely the events and indicate that the writers of these epics used this practice to increase their sales (Parmaksiz, 2006, p. 111). For example, "The Epic of the Tubercular Girl who Died at the Age of 18 without Satisfying her Life," "The Epic of the Woman who Died in Flames with her Four Children in Zonguldak." In these kinds of elegy epics, we also see the pictures of those involved in the incident, also on the printed page of the epic. With these pictures, possibly, the writers of the epics attempted to show its reality to the readers. Given the named cities, there are many examples from every part of Turkey, with examples from the cities of Izmir, Manisa, Giresun, Samsun, Ankara, Eskişehir, Sivas, Aydin, and Istanbul confirming this. Four hundred and two epics, published between 1955 and 1975, were evaluated in this study, principally to determine whether they contained the concept of death or not. There is a case of death in $52.2 \%$ of these epics $(n=210)$ and there is the concept of death in $47.8 \%$ of these epics (Table 1). There was more than one 
Table 1. The Recorded Cases of Death in Epics

\begin{tabular}{lcc}
\hline Death & $N$ & $\%$ \\
\hline Death is recorded & 210 & 52.2 \\
Death is absent & 192 & 47.8 \\
Total & 402 & 100 \\
\hline$\chi^{2}=0.717, p=0.397$. & &
\end{tabular}

written epic for the same event. In this context concerning death, there are 169 different cases of death recorded in these epics.

Two hundred and ten epics containing the concept of death were evaluated with content analysis. The findings obtained through this evaluation were as follows and are recorded in Table 2 . When the dispersion was analyzed according to the age of the deceased, for the dead person $63.7 \%$ of epics employed age as a defining characteristic with terms such as young, old, baby, child. Within a given age period, the term young was stressed for the dead person in $86.3 \%$ of these epics. When we take into consideration the content of the discussed epics, the age of the deceased is also recorded in $24.3 \%$ of these epics. When the age of demise is given in the epics is averaged, the mean age is 18,94 , the median age is 18 and the mode is 20 . Further, the deaths of young people are more noted as noteworthy and stressed in these epics (Table 2).

Excluding the gendered name of the deceased, $66.2 \%$ of the deaths include terms that denote the gender of the deceased. These terms are mostly as follows: girl, male, father, mother, bride, bridegroom, adolescent, etc.; $65.5 \%$ are men who carry gender definitions. The people for whom following their death epics were written, showed that over this period only $11.4 \%$ of them were important/famous (e.g., officer, religious leader, artist-craftsman, politician, etc.). In $31.4 \%$ of epics there is the desire for vengeance, $50 \%$ record the workings of fate, and in $96.7 \%$ of examples the manner of death is recorded (Table 2); $48.1 \%$ of these deaths are murders and of these the largest proportion, 21\%, were a consequence of the discharge of firearms. The largest proportion of accidental deaths were a consequence of traffic accidents (Tables 3, 4, and 5).

The proportion recording the perception of fate understood as the cause of death is as follows: as a result of disaster $87.5 \%$, as a result of accident $75.4 \%$, as a result of disease $66.7 \%$, as a result of suicide $62.5 \%$. The perception of fate as a cause of death does not exist in deaths by hanging and is $85.7 \%$ in martyr deaths and $60.6 \%$ in homicide deaths. There is no desire for vengeance in deaths caused through disease and disaster and very little from accidental deaths at $98.2 \%$. The proportion recording the desire for vengeance in martyr deaths is 
Table 2. Features of the Content of the Epics

\begin{tabular}{|c|c|c|c|}
\hline & $N$ & $\%$ & \\
\hline \multicolumn{4}{|c|}{ The record of the age of the deceased } \\
\hline Not recorded & 72 & 34.3 & \multirow[t]{6}{*}{$\chi^{2}=20.743, p=0.000$} \\
\hline Recorded & 138 & 65.7 & \\
\hline Young & 119 & 86.3 & \\
\hline Child & 12 & 8.6 & \\
\hline Old & 5 & 3.6 & \\
\hline Baby & 2 & 1.5 & \\
\hline \multicolumn{4}{|c|}{ Specification of gender } \\
\hline Not recorded & 71 & 33.8 & \multirow{4}{*}{$\chi^{2}=22.019, p=0.000$} \\
\hline Recorded & 139 & 66.2 & \\
\hline Female & 48 & 34.5 & \\
\hline Male & 91 & 65.5 & \\
\hline \multicolumn{4}{|l|}{ Age } \\
\hline Not recorded & 159 & 75.7 & \multirow{2}{*}{$\chi^{2}=55.543, p=0.000$} \\
\hline Recorded & 51 & 24.3 & \\
\hline \multicolumn{4}{|c|}{ Settlement name recorded } \\
\hline Not recorded & 44 & 21.0 & \multirow{4}{*}{$\chi^{2}=70.876, p=0.000$} \\
\hline Recorded & 166 & 79 & \\
\hline Urban & 97 & 58.4 & \\
\hline Rural & 69 & 41.6 & \\
\hline \multicolumn{4}{|c|}{ Desire for vengeance } \\
\hline Present & 66 & 31.4 & \multirow{2}{*}{$\chi^{2}=28.971, p=0.000$} \\
\hline Absent & 144 & 68.6 & \\
\hline \multicolumn{4}{|l|}{ Photograph } \\
\hline Present & 63 & 30.0 & \multirow{2}{*}{$\chi^{2}=33.600, p=0.000$} \\
\hline Absent & 147 & 70.0 & \\
\hline \multicolumn{4}{|c|}{ Perception of fate } \\
\hline Is present & 105 & 50.0 & \multirow{2}{*}{$\chi^{2}=0.000, p=1.000$} \\
\hline Is absent & 105 & 50.0 & \\
\hline \multicolumn{4}{|c|}{ The deceased is famous or not } \\
\hline Famous & 24 & 11.4 & \multirow{2}{*}{$\chi^{2}=124.971, p=0.000$} \\
\hline Not famous & 186 & 88.6 & \\
\hline \multicolumn{4}{|c|}{ Justification for the death } \\
\hline Not given & 48 & 22.9 & \multirow{2}{*}{$\chi^{2}=61.886, p=0.000$} \\
\hline Given & 162 & 67.1 & \\
\hline \multicolumn{4}{|l|}{ Manner of death } \\
\hline Not recorded & 7 & 3.3 & \multirow{3}{*}{$\chi^{2}=182.933, p=0.000$} \\
\hline Recorded & 203 & 96.7 & \\
\hline Total & 210 & 100 & \\
\hline
\end{tabular}


Table 3. The Proportion of Deaths

in Epics According to the

Type of Death

\begin{tabular}{lrr}
\hline Type of death & $N$ & $\%$ \\
\hline Homicide & 109 & 51.9 \\
Accident & 57 & 27.1 \\
Martyr & 21 & 10.0 \\
Suicide & 8 & 3.8 \\
Disaster & 8 & 3.8 \\
Disease & 6 & 2.9 \\
Execution & 1 & 0.5 \\
Total & 210 & 100 \\
\hline
\end{tabular}

$76.2 \%$ and in homicide deaths $44 \%$. The perception of fate in female deaths is $54.2 \%$, in male deaths $45.1 \%$. When we looked at the desire for vengeance, this desire exists in respect to women's death in $41.7 \%$ of examples, in men's death it is $31.9 \%$ (Tables 6 and 7). In deaths where there is a desire for vengeance, there is not the perception of fate, with a percentage of $75.2 \%$ (Table 8 ).

In epics where the fact of death is discussed, as in this statement, "I went along with the evil, what shall I say to whom?" the phenomenon of suicide is decried; but in a martyrs' death for the sake of the motherland, as in the expression "I don't die, I will become a martyr," these deaths are hallowed and it is even not accepted as being a death. When it is generally discussed, concerning the record of deaths in epics, emphasis was drawn to the following topics: the death of two brothers at the same time; when the deceased's wife is pregnant; the deceased's babies and children; the poverty of the father of the deceased; being killed by ones own relatives; death happening on the nuptial night; killing the members of one family by one who had become insane due to economic distress; kidnap and rape followed by murder; multiple deaths (traffic accident, disaster, etc.); to be a dead soldier; to be the religious leader of the deceased person; when the executed is believed to be not guilty; and death in an earthquake.

\section{DISCUSSION}

In the epics obtained from the National Library and those that are discussed here, mostly the cause of death is indicated. Death being a fact of life that each and every individual will face, and because of the fear derived from the rupture and obscurity caused by this phenomenon, death inevitably is a subject of interest. 
PERCEPTION OF DEATH IN TURKISH SOCIETY / 215

Table 4. The Proportion of Deaths According to the Immediate Cause

\begin{tabular}{lrr}
\hline Manner of death & $N$ & $\%$ \\
\hline Not specified & 7 & 3.3 \\
Firearms & 44 & 21.0 \\
Stab wound & 33 & 15.7 \\
Cutting with axe & 22 & 10.5 \\
Trauma & 15 & 7.1 \\
Smothering & 14 & 6.7 \\
Accident & 12 & 5.7 \\
Airline accident & 11 & 5.2 \\
Hanging & 8 & 3.8 \\
Anti-aircraft fire & 7 & 3.3 \\
Earthquake & 7 & 3.3 \\
Drowning & 5 & 2.4 \\
Accidental death through fire & 5 & 2.4 \\
Physical assault & 4 & 1.9 \\
Arson or murder through fire & 4 & 1.9 \\
Railway accident & 4 & 1.9 \\
Tuberculosis & 3 & 1.4 \\
Shipwreck & 2 & 1.0 \\
Hanging & 1 & 0.5 \\
Throwing a person off a high structure/place & 1 & 0.5 \\
Stoning & 1 & 0.5 \\
Total & 210 & 100 \\
\hline
\end{tabular}

This interest is frequently expressed in literature and causes people to read these works. Also, according to Parmaksiz, epics are written according to those issues that intrigue the individuals who constitute society and the priorities of the society. To provide this, the themes of these epics are chosen mainly from newspapers and from radio programs (Parmaksiz, 2006, p. 97). The epics featuring lament facilitate the sharing of pain and make death more bearable to society. Canetti (2007, p. 38) says that discourse of lament is an important factor in sharing grief and pain and it facilitates the admitting of death by the survivors of that death. 
Table 5. The Distribution of Deaths According to Reason Provided by the Epics

\begin{tabular}{lrr}
\hline Justification for the death & $N$ & $\%$ \\
\hline Not specified & 48 & 22.9 \\
Transport accident & 31 & 14.8 \\
$\quad$ Bus/Lorry accident & 12 & 5.7 \\
$\quad$ Railway accident & 9 & 4.3 \\
$\quad$ Car accident & 9 & 4.3 \\
Other transport accident & 1 & 0.5 \\
Sexual intercourse/honor killing & 29 & 13.8 \\
Economic & 26 & 12.4 \\
War/Military service & 16 & 7.6 \\
Airline accident & 12 & 5.7 \\
Accident & 9 & 4.3 \\
Disaster & 8 & 3.8 \\
Insanity & 7 & 3.3 \\
Combat & 6 & 2.9 \\
Religion & 5 & 2.4 \\
Disease/tuberculosis & 5 \\
Incest & 5 & 2.4 \\
Blood feud & 2 & 1.0 \\
Maritime accident & 2 & 1.0 \\
Revolution & 2 & 1.0 \\
Hanging & 10 & 0.5 \\
Total & & 0.5 \\
\hline & & 100 \\
\hline
\end{tabular}

In these epics, there is an emphasis on the death of the young, and in this emphasis the concept of "young" is employed. When the cases of death within a specified age period are examined, it is seen that the majority of them (96.4\%) are not elderly but are described as young, baby, or child. This leads to the opinion that the death of the elderly is more acceptable to society and elderly demise is assessed as being an unexceptional, natural occurrence causing no pain and therefore there is no need to share the pain, which is not the case with the death of the young. When we looked at the way epics treated people who are regarded as old, except for one case of death, the shared features of them are that they belong to elderly people killed by their sons. It can be said that the main variable 


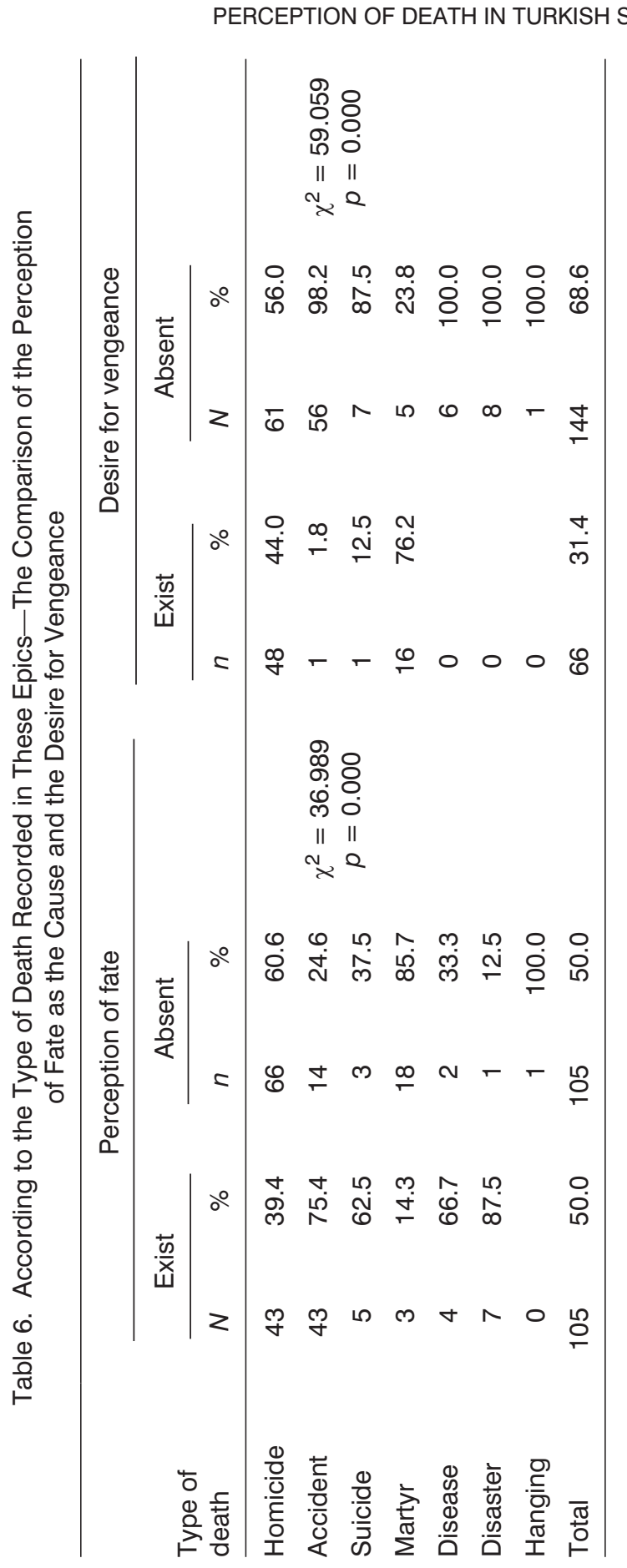




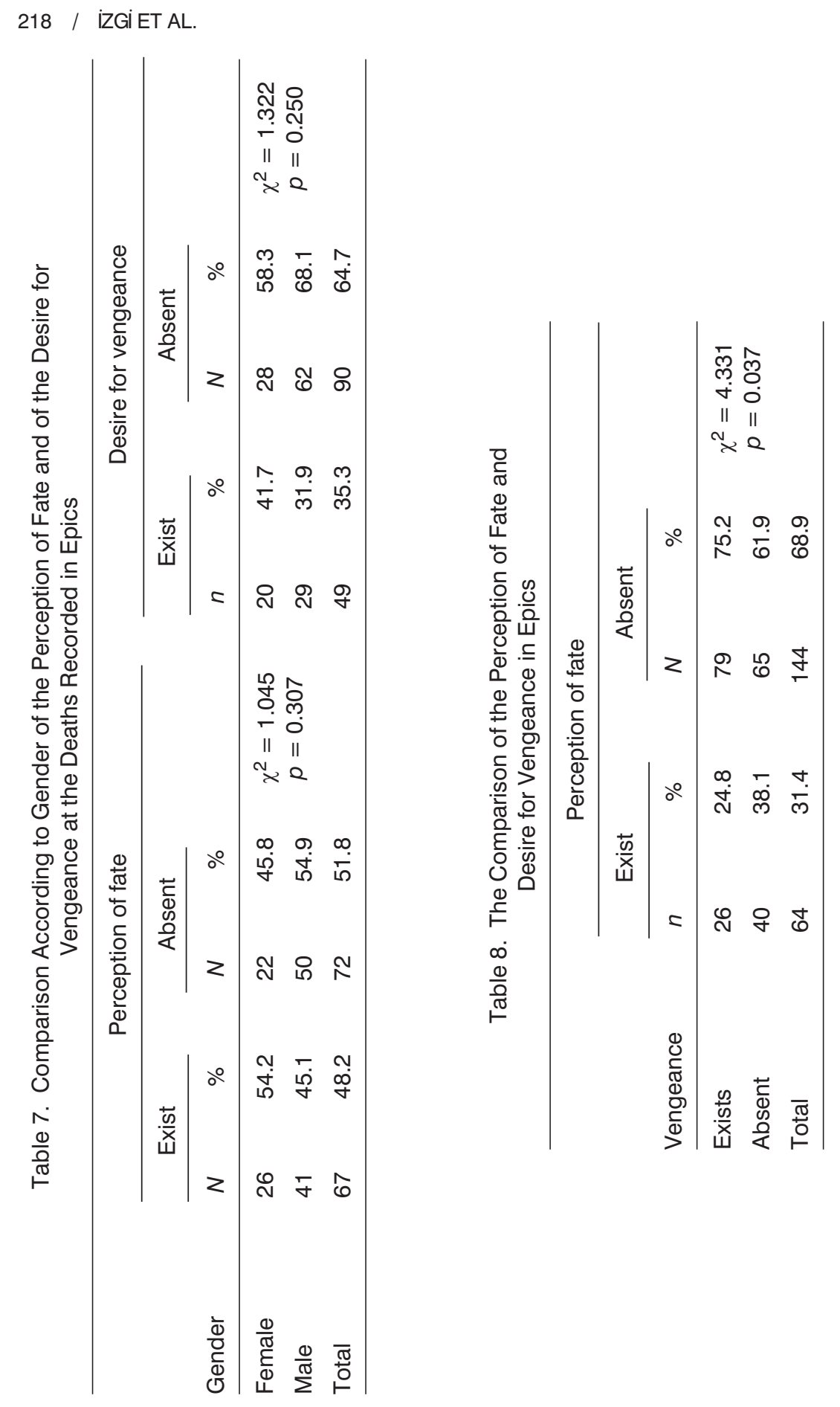


that determines them to be an epic, is to be killed by their son(s). In the context of physical age determining the criteria of old age, in epics the person who would be admittedly old having 67 years, is described as follows: "he died, 67 years old / he -Gümüşpala — was young for his nation." As we can understand from this example, the basic variable is "old"-"young" which is another important determinant.

Another factor shows that the age period is an important variable, although in $75.7 \%$ of the assessed epics the age of the person is not specified, but in $65.7 \%$ of epics the age of the person is expressed. Ergin (2009-2010, p. 182), in one of his studies, assessed epic notices in Turkish records: "Age rarely figures in these announcements" and that "age is rarely recorded in epic notices." This expression indicates it is the age group rather than the age in years which is more important. In the title of these epics, "The Epic of the Shot at a young age Halil İbrahimoğlu Son of Hüseyin from Piraziz's Gökçe Ali Village" and "The Epic of a Young Man Drowned by Three Cruel Men in Beykoz, Istanbul," the death at a young age is emphasized.

In the case of a young male who died in Kizilçelik, it is said this case ruptures the life of the deceased's relatives for a long time afterwards, the deceased's age, gender, position, and respectability in society determine the quantity of esteem given to whom in death. For example, if the deceased person were old, or a woman with a low status in society, they don't leave as tragic, sad traces upon their group and environments as the death of a "youth" (Kizilçelik, 2000, p. 136). There are also some studies in Western society (Chasteen \& Madey, 2003, p. 314) concerning the death of the young which are understood as being more tragic than the death of the elderly.

There are also some expressions that place the emphasis on the death of the young and the unacceptability of death at a young age:

- Ashyk (folk singer) Izzet feels great sadness over death at such a young age.

- Who wants death at an early age. ...

- I don't accept death at an early age / How many lives did Azrael take suddenly.

- My age was young / I didn't die growing old / My grave was dug, when I was young.

- I was young, when you covered me in the earth.

-... You didn't satisfy my youth, my age.

- Dying at this age, hurts me / Brother, I couldn't fulfil my life, what a cure!

- God took me away at a young age.

- I committed suicide at a young age.

- I was yet young, I couldn't attain my desire.

- Fate, they killed the youth, what a cure.

- They killed me, without satisfying my youth.

- In youth, cruel death is insufferable. 
Also, the deaths of babies, such as "pacifier in his mouth, her/his honey (baby) was died," express another value.

Another noteworthy component in epics is the connection of death with fate, because it provides a quicker acceptance of death by the people and it moderates the pain of a death at a young age. The following expressions support this:

- Ramazan took maul into his hand / He rammed my innocent Ismet against the wall / my wife was pregnant, but she couldn't give birth to a baby / That was fate, what shall I say and to whom.

- Let us obey fate / Let cry, whoever hears such pain.

- Doctors cannot find a cure for my trouble / Nobody can take him from the hands of fate.

- Don't cry friends, that was fate.

- Dying at an early age is wrong / What may we do, that is fate.

The belief in destiny was more highly expressed in deaths which occurred excluding the human factor and in the cases of unexpected deaths, as in a disaster or an accident. The association of death with fate decreases when avengers seek the person whom they think responsible for the death. The belief in destiny in natural deaths, which occur excluding the human factor, and at unexpected (unintentional) deaths is compatible with the belief that death comes from God, which forms the basis of belief in fate. This situation is also compatible with the lack of belief in fate in deaths where there is no desire for vengeance. As seen in the expression "that was fate, happenings are from the God," the concept of destiny is integrated with the religion. With the belief in death which comes from the God, the human anxiety over death may be lessened. As Yalom expressed it, anxiety over death and all other fears form the basis of religions. To bear this as creative power, fate - destiny - which God determines, makes people spiritually feel better and more able to overcome his/her fears (Yalom, 2008, p. 107). Ilechukwu (2007, p. 253), too, says that the sense of destiny enables people to hold on to life when their babies die.

According to a study of The House of Silence (2006), by Orhan Pamuk, Turks and eastern societies can cope with the fear of death through their understanding of fate and of thanksgiving.

According to Ashyk Ali Gürbüz, before becoming available for sale epics are given to the public prosecutor and the permission to publish is controlled by the judicial authorities, as to whether they are untrue or harmful to society and then, if the permission is granted, the epics are published (Parmaksiz, 2006, p. 103). As recorded above, with $31.4 \%$ exhibiting a desire for vengeance in the epics where death is studied and with permission given to print these epics, it is accepted that the desire for vengeance in these epics will not in fact lead to an increase in the rate of crime or to troubles in the subconscious mind. Although there is a desire for vengeance in epics, the permission to print these epics by the judicial authorities can be seen as due to the low probability of the actual realization of 
revenge by the reader, combined with the thought that the main function of the epics are to support the sharing of the pain of bereavement.

When we look at the existing case of the desire for vengeance according to the type of death in these epics, an entirely opposite situation is noticed in respect to the distribution of data obtained in the context of the phenomenon of fate. The desire for vengeance is rarely felt from deaths in a disaster or from a lethal accident caused through non human reasons, but it is more powerfully felt in situations such as war, where national sentiment is more intense.

While the desire for vengeance is expressed in epics, there are also some narratives concerning the person who will take revenge.

- Take revenge against that cruel man / Haul him over the coals, brother.

- Tell my fiancé Ahmet, let he come / Let he know he should investigate that treacherous enemy / Let him die godless, if he doesn't take my vengeance.

- I am dying without making my wish / Let my brother take my vengeance.

In these epics, $65.5 \%$ of deaths are male. Ergin studied the death notices in the newspapers and in this study, likewise, $71.1 \%$ of death notices concern males (2009/2010, p. 186). As can be seen, male deaths outnumber female deaths in the notification of deaths in both epics and death announcements. This indicates the importance of male deaths and is similar to the patriarchal social structure of Turkish society. We also find similar features in Azerbaijani with the same ethnic background, and the rubai of lament. When the Azerbaijani rubai of lament are generally discussed, it is known that while for the death of a child the number of laments are 10, for the male there are 26. A parallel situation can also be found in respect to the contents. Some examples which give more value to the males are recorded in the following verses: "die, let sister die / never die brothers," "let sister die rather than the brother / if brother dies, it is cruelty," and "at a home, if the brother dies / what can the sister do, without the brother." (Bayatilar; 1960, pp. 198-216).

When the distribution of the phenomenon of fate and the desire for vengeance are analysed according to gender, the statistically significant difference shows the factors affecting the fate and revenge variables are external variables of gender.

At the most, the handling of murder cases in epics was reconciled to attract more community attention. In the treatment of mortality in epics, except for those depending upon involuntary accident, the most common justifications for death are sexual relationships, the perception of honor, and for economic reasons. Today, too, when we consider the national press, the reporting of murder and of similar issues in the Turkish newspaper, called the third page news, it can be understood as the continuation of this same interest and it can also be understood that the announcement feature of the epics to society is today fulfilled in this way.

Accidents as a type of death in epics are secondary, and can be understood as a type for mass deaths. 
The relatively frequent use of an axe as a murder weapon in these epics can be understood as a form of death employed to attract more attention. As an axe is always used in daily life by people living in rural areas and in addition to its cutting, its bluntness of force increases the pain.

The perspectives of the social classes toward the event of death, to the conceptions of dead and death, methods of approach to the dead/death and the cultural values concerning death are different from each other. The people belonging to the dominant class in society find "natural" the event of death. For that reason, in the event of death they are more composed, calmer, formal - probably unnaturally so. However, the majority of people in society belonging to the silent masses, especially in Turkish society, almost collapse in the event of a death. The impact of death upon them is great and causes deep marks and effects (Kizilçelik, 2000 , p. 136). We see this in the discussed epics. In the epics we surveyed, 88.6 $\%$ of the people recorded in these epics belong to the silent majority.

\section{CONCLUSIONS}

In Turkish culture and literature, until the middle of the 1970s, the one page epic served to draw attention and to increase the sensitivity of the people. To achieve this, evaluated themes are mostly performed with the actual events. The epics in the past also fulfilled the feature of annunciation. In those epics concerning death, they largely retell the death cases, the manners and reasons for death, the approximate age of the deceased, and the gender. In general, these people are not famous, they are members of the public. The use of a photograph would serve to increase the interest in these epics, but in these published works it would be more expensive and as a consequence a photograph of the deceased was rarely employed in the published epics.

Except for the victims of homicide and for martyrs, there is an emphasis upon the perception of fate in most cases of death. Making death the result of fate in accordance with belief, the attempt is made to reduce the pain brought about by death. In those epics concerning the desire for vengeance, the person who will exact vengeance is denoted, and it is thought this helps to consolidate the sense of a blood feud. In these epics, there is more emphasis placed upon the death of the young, which is described as untimely. In this way these lament epics from 1955 to 1975 provide information concerning death, and the way that the feelings of the bereaved are expressed reflects the socio-cultural perception of death in Turkish society.

\section{REFERENCES}

Bayatilar. (1960). ed. H. Gasymov, Azerneşr, Baku.

Canetti, E. (2007). Ölüm Üzerine (Über Den Tod), trans. by Gürsel Aytaç, Payel Yayinevi, İstanbul. 
Chasteen, A. L., \& Madey S. F. (2003). Belief in a just world and the perceived injustice of dying young or old. Omega: Journal of Death and Dying, 47(4), 313-326.

Ergin, M. (2009-2010). Taking it to the grave: Gender, cultural capital, and ethnicity in Turkish death announcements. Omega: Journal of Death and Dying, 60(2), 175-197.

Ilechukwu, S. T. C. (2007). Ogbanje/abiku and cultural conceptualizations of psychopathology in Nigeria. Mental Health, Religion \& Culture, 10(3), 239-255.

Kizilçelik, S. (2000). Sosyoloji Yazilari II, Ani Yayincilik. Ankara, 137-138.

Pamuk, O. (2006). Sessiz Ev (The House of Silence), İletişim Yayinlari, İstanbul.

Parmaksiz, N. M. (2006). Asik Edebiyatinda Agit Konulu Destanlar. Unpublished Master thesis, Gazi Üniversitesi Sosyal Bilimler Enstitüsü, Ankara.

Yalom, I. (2008). Günese bakmak ölümle yüzlesmek (Staring at the sun-Overcoming the terror of death). trans. by Zeliha İyidoğan Babayiğit, İstanbul.

Direct reprint requests to:

M. Cumhur Izgi

Akdeniz University

Dept. of Medicine History \& Ethics

Antalya, Turkey

e-mail: cizgi@akdeniz.edu.tr 
Copyright of Omega: Journal of Death \& Dying is the property of Baywood Publishing Company, Inc. and its content may not be copied or emailed to multiple sites or posted to a listserv without the copyright holder's express written permission. However, users may print, download, or email articles for individual use. 